\title{
PENGARUH LAYANAN JEMPUT BOLA PRODUK FUNDING TERHADAP DPK DAN JUMLAH NASABAH: STUDI PADA BPRS ARTHA KARIMAH IRSYADI
}

\author{
Hendri Triandini \\ Universitas Prof. Muhammadiyah Dr. Hamka
}

\begin{abstract}
The Impact of Funding Product Proactive Services to Third Party Funds and Customer Number: Studies in BPRS Artha Karimah Irsyadi. The purpose of this study was to analyze the effect of funding product proactive service to the number of customers. Proactive services is considered as something superior to the BPRS Irsyadi in 2010, because the BUS not familiar with this system. But apparently once held more detailed testing using hypothesis testing and regression test dummy variables, the increase in deposits and a significant number of customers, not due to proactive services independently but other factors, the margins, and CAR. However, although the service is proactive not affect independently, the service is likely to proactive services into effect on the increase in deposits and the number of customers independently, if the system is further improved quality, both internal and external factors.
\end{abstract}

Keywords: proactive services, third party funds, dummy variable regression

Abstrak. Pengaruh Layanan Jemput Bola Produk Funding Terhadap DPK dan Jumlah Nasabah: Studi Pada BPRS Artha Karimah Irsyadi. Tujuan penelitian ini ialah untuk menganalisis pengaruh layanan jemput bola produk funding terhadap DPK serta jumlah nasabah. Layanan jemput bola dianggap sebagai sesuatu yang unggul dari BPRS Irsyadi pada 2010, karena BUS belum mengenal sistem ini. Namun ternyata setelah diadakan pengujian lebih terperinci menggunakan uji hipotesis dan uji regresi dummy variable, peningkatan DPK dan jumlah nasabah yang signifikan tersebut, bukan disebabkan oleh layanan jemput bola secara independen tetapi faktor lain, yaitu margin, dan KPMM. Namun, meskipun layanan jemput bola belum berpengaruh secara independen, besar kemungkinan untuk layanan jemput bola menjadi berpengaruh terhadap kenaikan DPK dan jumlah nasabah secara independen, bila sistemnya lebih ditingkatkan kualitasnya, baik dari faktor internal maupun eksternal.

Kata Kunci: layanan jemput bola, dana pihak ketiga, regresi variabel dummy 


\section{PENDAHULUAN}

Fungsi utama BPRS sama saja seperti bank syariah pada umumnya. Hanya saja sasaran dari BPRS lebih sempit dibandingkan bank syariah pada umumnya, yang memiliki sasaran lebih luas. Hal tersebutlah yang membedakan antara BPRS (Bank Pembiayaan Rakyat Syariah) dengan BUS (Bank Umum Syariah). Tujuan antara BPRS dengan BUS pun juga sama-sama mencari profit, dengan melakukan kegiatan-kegiatan perbankan.

Semakin besar keuntungannya maka semakin dianggap baik kinerja suatu bank. Untuk mendapatkan keuntungan yang lebih lagi, bank syariah terus merambah keberbagai hal dalam menawarkan produknya. Hingga saat ini, bank syariah telah menawarkan produk-produk yang sebenarnya merupakan kegiatan usaha dari lembaga keuangan syariah selain bank syariah sendiri, semisal mengumpulkan dana wakaf, zakat, bahkan sampai ke gadai menggadai.

Hal tersebutlah yang justru akan menimbulkan masalah, yaitu mulai terancamnya lembaga keuangan syariah lain karena bagiannya mulai dikuasai oleh BUS. Termasuk juga dengan BPRS. Salah satu BPRS yang tanggap terhadap situasi ini, adalah BPRS Artha Karimah Irsyadi. BPRS Irsyadi memberikan satu nilai plus yang tidak dilakukan BUS di tahun 2010 yaitu, layanan jemput bola.

Strategi jemput bola ini dilakukan oleh BPRS Irsyadi sebagai salah satu strategi promosi yang berupaya mendekatkan diri kepada masyarakat dengan cara mempermudah nasabah untuk mengakses layanan di BPRS Irsyadi. Untuk menghadapi pasar sasaran yang ada, perbankan menghadapi banyak kesulitan, seperti munculnya bank-baru baru, pembaharuan teknologi, kemudahan bertransaksi, aneka ragam hadiah dan promosi yang ditawarkan oleh bank, dan sebagainya. Untuk tetap mempertahankan dan meningkatkan jumlah nasabah, stabilitas dan kemampuan laba, maka pemasaran dapat melakukan dua cara yaitu dengan tetap fokus pada pasar yang sudah ada. Selain itu bank juga harus memikirkan kemungkinan untuk membuka cabang-cabang baru atau mendirikan beberapa perwakilan di berbagai tempat yang cukup strategis bagi pengembangan organisasi.

Hal ini dilakukan sebagai upaya melakukan penetrasi pasar. Penetrasi pasar atau penerobosan pasar merupakan usaha perusahaan (bank) 
meningkatkan jumlah nasabah baik secara kuantitas maupun kualitas pada pasar saat ini (lama) melalui promosi dan distribusi secara aktif. Strategi ini cocok untuk pasar yang sedang tumbuh dengan lamban. Perusahaan berusaha melakukan strategi pemasaran yang mampu menjangkau atau menggairahkan pasar yang sedang tumbuh secara lamban agar mampu tumbuh secara cepat.

Seperti teori ekonomi yang ada biaya promosi berbanding lurus dengan pendapatan. Dan bila diterapkan dalam kasus ini, layanan jemput bola merupakan salah satu sarana promosi bagi BPRS Irsyadi dan tentu saja menggunakan biaya promosi. Jika sesuai dengan teori, seharusnya jumlah Dana Pihak Ketiga (DPK) BPRS Irsyadi yang terdiri dari dana nasabah tabungan dan deposito, begitupula dengan jumlah nasabah funding akan semakin meningkat dengan adanya layanan jemput bola. Namun kenyataan yang ada justru tidak sesuai dengan data jumlah DPK dan jumlah nasabah BPRS Irsyadi.

Untuk itulah penulis meneliti pengaruh dari layanan jemput bola sendiri terhadap peningkatan jumlah DPK dan jumlah nasabah BPRS Irsyadi. Tujuan dari penelitian ini adalah: pertama, untuk mengetahui pengaruh layanan jemput bola secara parsial terhadap DPK dan jumlah nasabah produk funding pada BPRS Irsyadi. Kedua, untuk mengetahui pengaruh layanan jemput bola secara simultan terhadap DPK dan jumlah nasabah produk funding pada BPRS Irsyadi.

\section{METODE}

Penelitian ini menggunakan teknik analisis regresi dummy variable, yang tentunya data diuji terlebih dahulu menggunakan uji asumsi klasik dan uji hipotesis. Alasan penulis menggunakan teknik analisis regresi dummy variable ialah karena dalam penelitian ini, layanan jemput bola merupakan variabel kualitatif karena tidak memiliki nilai yang dapat diukur, sehingga layanan jemput bola merupakan variabel bebas yang merangkap sebagai variabel boneka atau dummy variable. Selain layanan jemput bola, variabel bebas lainnya antara lain margin (equivalent rate 1 bulan deposito) dan KPMM (CAR) yang bernilai persentase. Selain menjadi variabel bebas, margin dan KPMM juga merangkap sebagai variabel kontrol. Untuk variabel terikat dalam penelitian ini ialah jumlah DPK dan jumlah nasabah. 
Uji asumsi klasik yang digunakan antara lain, uji normalitas untuk mengetahui berdistribusi normal atau tidakkah variabel, uji heteroskedastisitas untuk mengetahui apakah model regresi terjadi ketidaksamaan variance dari residual satu pengamatan, ke pengamatan yang lainnya, uji autokorelasi untuk mengetahui apakah dalam suatu model regresi linear ada korelasi antara kesalahan pengganggu pada periode $\mathrm{t}$ dengan kesalahan pada periode $\mathrm{t}-1$ (sebelumnya), dan yang terakhir ialah uji multikolinieritas digunakan untuk mengetahui apakah model regresi ditemukan adanya korelasi antar variabel bebas (independent).

Selain itu, uji hipotesis yang terdiri dari uji-t, uji F, dan uji koefisien determinasi $\left(\mathrm{R}^{2}\right)$ juga digunakan dalam penelitian ini. Uji-t berguna untuk menguji pengaruh variabel bebas secara parsial terhadap variabel terikat. Uji $F$ berguna untuk menguji pengaruh variabel bebas secara simultan atau keseluruhan terhadap variabel terikat. Uji koefisien determinasi digunakan untuk mengukur seberapa jauh kemampuan model regresi dalam menerangkan variasi variabel dependen (variabel terikat).

\section{PEMBAHASAN}

Penulis melakukan wawancara dengan pihak BPRS Irsyadi dengan narasumber langsung dari pihak BPRS Irsyadi yaitu Bapak Faisal Amir selaku Kepala Bagian Operasional. Wawancara ini dilakukan dengan tujuan memperkuat data mengenai layanan jemput bola ini sendiri demi kelangsungan penelitian. Dari hasil wawancara dapat kita simpulkan bahwa BPRS Irsyadi mulai beroperasi sejak 9 November 1992. Struktur organisasi BPRS Irsyadi pun sama seperti bank syariah lain, hanya saja ada beberapa pegawai yang merangkap jabatannya. Program layanan yang ada di BPRS Irsyadi antara lain yaitu, layanan jemput bola serta pemberian souvenir untuk setiap pembukaan deposito.

Layanan jemput bola produk funding pada BPRS Irsyadi merupakan inti dari penelitian ini. Menurut BPRS Irsyadi, layanan jemput bola ialah layanan tambahan bagi nasabah tabungan, maupun deposito, dimana nasabah dipermudah untuk pembukaan tabungan/deposito maupun penyetoran tabungan/deposito dengan didatangi oleh marketing funding BPRS Irsyadi 
sehingga nasabah tidak repot untuk datang ke BPRS. Layanan ini hadir sejak tahun 2010 semester awal. Alasan dari hadirnya layanan ini ialah untuk meningkatkan jumlah DPK untuk mencapai target penghimpunan dana, dan untuk menarik minat nasabah untuk menabung ataupun mendepositkan dananya di BPRS Irsyadi.

Sasaran dari layanan jemput bola ini ialah masyarakat umum, instansiinstansi, dan lain sebagainya yang merupakan nasabah maupun calon nasabah tabungan dan deposito. Keuntungan dengan hadirnya layanan ini bagi bank ialah untuk menarik minat nasabah funding untuk menabung atau mendepositkan dananya pada BPRS Irsyadi, sedangkan bagi nasabah ialah layanan ini mempermudah mereka karena nasabah tidak perlu datang ke BPRS jika ingin menabung atau mendepositkan dananya pada BPRS, sehingga dapat menghemat waktu serta biaya nasabah. Layanan jemput bola ini memiliki persyaratan yang cukup mudah, yaitu hanya cukup menjadi nasabah produk tabungan maupun deposito di BPRS Irsyadi saja. Menurut pihak BPRS Irsyadi, kendala yang biasa dihadapi, antara lain ialah faktor jarak lokasi nasabah, nominal yang akan diserahkan, dan waktu marketing yang terbatas. Namun BPRS Irsyadi memiliki trik khusus dalam menghadapi kendala tersebut di antaranya ialah untuk jarak menggunakan layanan e-banking dari bank lain yang bekerja sama dengan BPRS Irsyadi, jadi nasabah hanya tinggal mentransfer dananya saja, dan marketing BPRS Irsyadilah yang akan mengambil ke bank tersebut. Untuk nominal, BPRS Irsyadi membatasi dengan nominal minimum yaitu 20 juta ke atas. Dan untuk kendala yang terakhir yaitu, waktu marketing yang terbatas, diantisipasi dengan cara, pihak BPRS Irsyadi akan semaksimal mungkin berusaha menyempatkan waktu dan memberikan pelayanan terbaik bagi nasabah yang ingin menggunakan layanan jemput bola.

Dari hasil uji- $t$ untuk variabel dependen jumlah DPK, diperoleh tingkat signifikan pada variabel layanan jemput bola tidak memiliki pengaruh terhadap variabel jumlah DPK. Untuk margin memiliki pengaruh terhadap variabel jumlah DPK. Dan untuk KPMM diperoleh signifikan di bawah nilai yang telah ditentukan, berarti variabel KPMM/CAR memiliki pengaruh terhadap variabel jumlah DPK. 
Dari hasil uji-t untuk variabel dependen jumlah nasabah, diperoleh tingkat signifikan pada variabel layanan jemput bola tidak memiliki pengaruh terhadap variabel jumlah DPK. Untuk margin memiliki pengaruh terhadap variabel jumlah nasabah. Untuk KPMM memiliki pengaruh terhadap variabel jumlah nasabah.

Bedasarkan pengujian statistik dengan menggunakan metode uji koefisien determinasi $\left(\mathrm{R}^{2}\right)$ untuk variabel dependen jumlah DPK, diperoleh nilai Adjusted $\mathrm{R}^{2}$ sebesar 0.799. Hal ini menunjukkan bahwa persentase sumbangan pengaruh variabel independen terhadap variabel dependen sebesar 79.9\%. Karena R dalam Adjusted R Square hampir mendekati angka 1 atau variasi variabel independen yang digunakan dalam model mampu menjelaskan sebesar 79.9\% variasi variabel dependen. Sedangkan sisanya sebesar $20.1 \%$ dipengaruhi atau dijelaskan oleh variabel lain yang tidak dimasukkan dalam model penelitian ini.

Berdasarkan pengujian statistik dengan menggunakan metode uji koefisien determinasi $\left(\mathrm{R}^{2}\right)$ untuk variabel dependen jumlah nasabah, diperoleh nilai Adjusted $\mathrm{R}^{2}$ sebesar 0.836. Hal ini menunjukkan bahwa persentase sumbangan pengaruh variabel independen terhadap variabel dependen sebesar 83.6\%. Karena R dalam Adjusted R Square hampir mendekati angka 1 atau variasi variabel independen yang digunakan dalam model mampu menjelaskan sebesar $83.6 \%$ variasi variabel dependen. Sedangkan sisanya sebesar $16.4 \%$ dipengaruhi atau dijelaskan oleh variabel lain yang tidak dimasukkan dalam model penelitian ini.

Dari hasil pembahasan dan hasil uji statistik di atas menunjukan bahwa layanan jemput bola tidak memiliki pengaruh yang signifikan terhadap jumlah DPK dan jumlah nasabah. Akan tetapi, variabel lainnya seperti margin/rate, dan KPMM memiliki pengaruh yang signifikan terhadap jumlah DPK dan jumlah nasabah.

Dari hasil yang ada, layanan jemput bola tidak memiliki pengaruh yang signifikan terhadap jumlah DPK dan jumlah nasabah secara independen. Hal ini terbukti dari hasil perhitungannya dianalisis regresi dummy variable dan hasil dari uji-t. Dari keduanya, layanan jemput bola tidak memiliki pengaruh yang signifikan. Dalam teorinya, layanan jemput bola yang merupakan salah satu 
sarana promosi tentunya menggunakan biaya promosi, seharusnya berbanding lurus dengan peningkatan jumlah DPK dan nasabah. Hal tersebut dikarenakan semakin besar biaya promosi yang dikeluarkan, maka semakin besar pula pendapatan bank. Namun berbeda dengan keadaan real-nya yang didasarkan oleh hasil uji regresi dummy variable dan uji-t. Hasil dari uji-uji tersebut menyatakan bahwa teori yang disebutkan di atas, tidak berlaku karena layanan jemput bola tidak mempengaruhi peningkatan jumlah DPK dan nasabah.

Hal ini dapat dipengaruhi banyak hal. Dan yang penulis tangkap dari hasil analisis regresi dummy variable, uji-t, serta hasil wawancara dengan pihak BPRS Irsyadi langsung, layanan jemput bola tidak memiliki pengaruh yang signifikan dalam peningkatan jumlah DPK dan nasabah, terjadi karena pertama, ruang lingkup BPRS yang belum meluas, kedua metode promosi yang kurang efektif, dan yang ketiga ialah permasalahan-permasalahan teknis pada marketing funding-nya sendiri sehingga layanan jemput bola di BPRS Irsyadi tidak memiliki pengaruh pada peningkatan jumlah DPK dan nasabah secara parsial.

Dari hasil yang ada, variabel margin memiliki pengaruh yang signifikan terhadap jumlah DPK dan jumlah nasabah. Hal ini terbukti dari hasil perhitungannya di analisis regresi dummy variable dan hasil dari uji-t. Dari keduanya, margin memiliki pengaruh yang signifikan terhadap jumlah DPK. Begitupula untuk yang jumlah nasabah, margin memiliki pengaruh yang signifikan. Dari hasil tersebut bisa kita kaitkan ke dalam teorinya, di mana margin atau dalam bank syariah yaitu equivalent rate 1 bulan deposito, berpengaruh secara parsial terhadap peningkatan jumlah DPK dan nasabah. Artinya margin atau equivalent rate 1 bulan deposito di BPRS Irsyadi, cukup menarik minat para calon deposan pada BPRS Irsyadi. Hal tersebut menyebabkan para deposan yang tertarik akan besaran tingkat equivalent rate yang ada pada BPRS Irsyadi ini akan dengan puas mendepositkan dananya di BPRS Irsyadi.

Dari hasil yang ada, variabel KPMM memiliki pengaruh yang signifikan terhadap jumlah DPK dan jumlah nasabah secara independen. Hal ini terbukti dari hasil perhitungannya di analisis regresi dummy variable dan hasil dari uji-t. Dari keduanya, KPMM memiliki pengaruh yang signifikan. Pada teorinya, rasio 
modal atas simpanan cukup dengan 10\% dan dengan rasio itu permodalan bank dianggap sehat. Namun, dalam keadaan real-nya, KPMM, berpengaruh secara parsial terhadap peningkatan jumlah DPK dan nasabah. Hal ini terjadi kemungkinan karena, peringkat dari KPMM BPRS Irsyadi berada pada tingkat 1 yang artinya besar KPMM > 12\%, artinya modal BPRS Irsyadi tergolong sehat permodalannya. Oleh karenanya keadaan BPRS Irsyadi berada dalam status likuid dan nasabah tidak perlu ragu jika ingin mendepositkan dananya serta menabungkan dananya di BPRS Irsyadi. Hal ini dikarenakan status bank yang likuid, sehingga kapanpun nasabah ingin menarik dananya, BPRS Irsyadi selalu siap, terlebih untuk produk deposito yang jika nasabah menarik dananya sebelum jatuh tempo pun tidak akan dikenakan pinalty. Oleh karena itu, banyak calon nasabah ataupun yang telah menjadi nasabah tertarik untuk menyimpan dan mendepositkan dananya di BPRS karena tertarik akan kelikuidan BPRS Irsyadi sendiri, sehingga semakin tinggi tingkat KPMM atau status likuiditas BPRS Irsyadi, maka semakin tinggi pula dana DPK dan jumlah nasabah funding nya.

Ulfa (2011) yang bertujuan untuk melihat efektivitas strategi jemput bola di DUTA BMT. Dalam melaksanakan strategi pemasaran jemput bola pihak UJKS-BMT Mitra Umat Pekalongan dapat dikatakan efektif, hal ini dapat dilihat dari peningkatan jumlah nasabahnya Pemasaran yang dilakukan dengan cara seluruh karyawan BMT terutama bagian marketing menjadi DUTA BMT yang diharapkan dapat mempromosikan produknya sehingga laku terjual di pasaran dan jumlah nasabah pun meningkat.

Rofiaty (2005) dari hasil pengujian yang dilakukan menunjukkan bahwa hasil uji F terbukti secara bersama-sama variabel implementasi strategi fungsional yang terdiri dari empat variabel berpengaruh secara signifikan terhadap keberhasilan penerapan corporate strategy, dengan hasil perhitungan regresi berganda diketahui bahwa variabel operasional memiliki pengaruh terhadap variabel dependen sebesar 0,71, variabel keuangan sebesar 0,85, variabel pemasaran sebesar 0,56, dan variabel SDM sebesar 0,52. Dari hasil uji t dapat disimpulkan bahwa variabel pemasaran merupakan variabel yang memiliki pengaruh paling dominan, hal ini terbukti bahwa BPRS harus dan telah 
menerapkan layanan jemput bola dengan aktif mendatangi nasabah baik lending maupun funding yaitu sebesar 4,03\% terhadap keberhasilan penerapan corporate strategy.

Hariyani (2012) melakukan penelitian yang salah satunya bertujuan untuk mengetahui cara penghimpunan dana yang dilakukan oleh BPRS Lantabur. Metode yang dipergunakan ialah penelitian kualitatif dengan penelitian studi kasus. Hasil penelitian menyimpulkan bahwa penghimpunan dana di BPRS Lantabur dilakukan dengan strategi jemput bola dan captive market dengan menawarkan tingkat bagi hasil yang sangat kompetitif yaitu untuk produk tabungan bagi hasil setara 6 - 8\% dan produk deposito setara 8 $10 \%$ dengan pola bagi hasil secara revenue sharing. Oleh karenanya semua lokasi kantor BPRS Lantabur terletak di sekitar pasar, hal ini bertujuan untuk menjaring para pedagang/pengusaha kecil.

Annisa (2013) mengadakan penelitian terkait untuk mengetahui persepsi nasabah terhadap sistem yang diberlakukan pada BMT ANDA Salatiga dalam pemasaran yaitu sistem jemput bola atau sistem dengan mendatangi nasabah. Dalam penelitian ini ditemukan bahwa sistmen jemput bola ini memiliki imbas terhadap kesetiaan nasabah di BMT ANDA Salatiga, dan selanjutnya akan meningkatkan dana pihak ketiga.

Perbedaan antara hasil yang didapat oleh Annisa (2013) dengan penelitian ini terkait layanan jemput bola di BPRS Irsyadi masih belum berpengaruh terhadap jumlah DPK dan nasabah disebabkan oleh: pertama, ruang lingkup BPRS yang belum meluas, karena BPRS Irsyadi belum memiliki cabang ataupun kantor kas. Kedua, metode promosi yang kurang efektif atau kurangnya sosialisasi pada masyarakat mengenai keuntungan khusus dari layanan jemput bola ini, dan; Ketiga ialah permasalahan-permasalahan teknis pada marketing funding-nya sendiri, seperti kurangnya tenaga marketing funding karena beberapa marketingnya masih merangkap juga sebagai marketing financing.

Oleh karenanya untuk penyempurnaan layanan jemput bola di BPRS Irsyadi perlu dilakukan beberapa perbaikan diantaranya ialah: pertama, menambah keterjangkauan BPRS Irsyadi, meskipun BPRS Irsyadi belum 
memiliki kantor cabang ataupun kantor kas, namun apabila BPRS mampu meluaskan jaringannya maka akan lebih mampu menaikkan jumlah nasabah serta dana pihak ketiga di bank syariah. Kedua, perlu dilakukan sosialisasi dan promosi yang lebih gencar kepada masyarakat baik kepada nasabah lama maupun kepada calon nasabah mengenai layanan ini. Layanan jemput bola ini akan memberikan manfaat bagi nasabah yang memiliki tingkat mobilitas tinggi, karena mereka tidak harus datang ke lokasi kantor BPRS tetapi dananya dapat diambil oleh pihak BPRS. Ketiga, perlu menambah jumlah sumber daya manusia terutama di sisi tenaga marketing fundingnya. Semakin banyak tenaga marketingnya, maka akan semakin memperkuat perbaikan layanan jemput bola ini ke depannya.

Sebagaimana yang telah diketahui dari berbagai kajian literatur bahwa terdapat beberapa faktor yang dapat mempengaruhi jumlah dana pihak ketiga dan jumlah nasabah di bank syariah, yaitu faktor internal dan faktor eksternal. Faktor internal diantaranya ditunjukkan dengan kinerja keuangan seperti tingkat marjin, tingkat kesehatan bank yang ditunjukkan dengan NPF dan CAR, tingkat profitabilitas, dll.

Faktor eksternal mencakup tingkat marjin yang ditawarkan oleh pesaing -dalam hal ini pesaing BPRS dapat berasal dari sesama BPRS atau dari Bank Umum Syariah-, tingkat bunga yang ditawarkan oleh bank konvensional, dan indikator makroekonomi, seperti tingkat inflasi, tingkat pertumbuhan ekonomi, dan nilai tukar. Oleh karenanya strategi jemput bola masih menjadi bagian yang kecil dalam keputusan pemilihan rekening oleh para calon nasabah, karena para calon nasabah memiliki beberapa pertimbangan lain ketika mereka memutuskan untuk menaruh dananya di suatu bank baik bank syariah maupun bank konvensional.

BPRS Irsyadi harus mampu memadukan berbagai strategi baik yang sifatnya strategi pemasaran seperti layanan jemput bola ini, namun turut pula harus menunjukkan kinerja yang baik kepada masyarakat. Kinerja keuangan yang baik akan memberikan suatu stimulasi kepada para calon nasabah untuk yakin bahwa BPRS yang dipilih merupakan lembaga perbankan yang aman dan dapat dipercaya untuk menyimpan dana mereka. Perbaikan layanan dan kinerja 
yang dilakukan secara berkesinambungan akan mampu meyakinkan para calon nasabah mengenai kondisi BPRS.

Pelatihan dan pengembangan kualitas sumber daya manusia harus dilakukan secara berkesinambungan terutama pelatihan kepada para marketing dan front liner yang langsung berhadapan dengan para nasabah dan calon nasabah untuk memberikan informasi yang tepat dan baik mengenai kondisi BPRS. Setiap karyawan BPRS Irsyadi harus mampu menjadi tenaga marketing funding, terlepas dari jabatan mereka di BPRS. Seluruh karyawan memiliki kewajiban untuk menarik nasabah dan meningkatkan dana pihak ketiga.

BPRS Irsyadi sebagai salah satu lembaga keuangan syariah tentu harus menerapkan suatu strategi pemasaran syariah. Pemasaran syariah sendiri menurut definisi adalah adalah penerapan suatu disiplin bisnis strategis yang sesuai dengan nilai dan prinsip syariah. Jadi pemasaran syariah dijalankan berdasarkan konsep keIslaman yang telah diajarkan Nabi Muhammad SAW. Menurut Hermawan Kartajaya, nilai inti dari pemasaran syariah adalah integritas dan transparansi, sehingga marketer tidak boleh bohong dan orang membeli karena butuh dan sesuai dengan keinginan dan kebutuhan, bukan karena diskonnya atau iming-iming hadiah belaka.

Konsep pemasaran syariah sendiri sebenarnya tidak berbeda jauh dari konsep pemasaran yang kita kenal. Konsep pemasaran yang kita kenal sekarang, pemasaran adalah sebuah ilmu dan seni yang mengarah pada proses penciptaan, penyampaian, dan pengkomunikasian values kepada para konsumen serta menjaga hubungan dengan para stakeholdersnya. Namun pemasaran sekarang menurut Hermawan juga ada sebuah kelirumologi yang diartikan untuk membujuk orang belanja sebanyak-banyaknya atau pemasaran yang pada akhirnya membuat kemasan sebaik-baiknya padahal produknya tidak bagus atau membujuk dengan segala cara agar orang mau bergabung dan belanja. Berbedanya adalah pemasaran syariah mengajarkan pemasar untuk jujur pada konsumen atau orang lain. Nilai-nilai syariah mencegah pemasar terperosok pada kelirumologi itu tadi karena ada nilai-nilai yang harus dijunjung oleh seorang pemasar. Pemasaran syariah bukan hanya sebuah teknik pemasaran yang ditambahkan syariah karena ada nilai-nilai lebih pada 
marketing syariah saja, tetapi lebih jauhnya marketing berperan dalam syariah dan syariah berperan dalam pemasaran. Pemasaran berperan dalam syariah diartikan perusahaan yang berbasis syariah diharapkan dapat bekerja dan bersikap profesional dalam dunia bisnis, karena dengan profesionalitas dapat menumbuhkan kepercayaan kosumen. Syariah berperan dalam pemasaran bermakna suatu pemahaman akan pentingnya nilai-nilai etika dan moralitas pada pemasaran, sehingga diharapkan perusahaan tidak akan serta merta menjalankan bisnisnya demi keuntungan pribadi saja ia juga harus berusaha untuk menciptakan dan menawarkan bahkan dapat merubah suatu values kepada para stakeholders sehingga perusahaan tersebut dapat menjaga keseimbangan laju bisnisnya sehingga menjadi bisnis yang stabil dan berkelanjutan.

Dalam hal teknis pemasaran syariah, salah satunya terdapat strategi pemasaran syariah untuk memenangkan mind-share dan nilai pemasaran syariah untuk memenangkan heart-share. Strategi pemasaran syariah melakukan segmentasi, targeting dan positioning market dengan melihat pertumbuhan pasar, keunggulan kompetitif, dan situasi persaingan sehingga dapat melihat potensi pasar yang baik agar dapat memenangkan mind-share. Selanjutnya syariah marketing value melihat brand sebagai nama baik yang menjadi identitas seseorang atau perusahaan, sehingga contohnya perusahaan yang mendapatkan the best customer service dalam bisnisnya sehingga mampu mendapatkan heart-share.

Konsep pemasaran syariah ini sendiri saat ini baru berkembang seiring berkembangnya ekonomi syariah. Beberapa perusahaan dan bank khususnya yang berbasis syariah telah menerapkan konsep ini dan telah mendapatkan hasil yang positif. Kedepannya diprediksikan marketing syariah ini akan terus berkembang dan dipercaya masyarakat karena nilai-nilainya yang sesuai dengan apa yang dibutuhkan masyarakat yaitu kejujuran. Secara umum pemasaran syariah adalah sebuah disiplin bisnis strategi yang mengarahkan proses penciptaan, penawaran dan perubahan value dari inisiator kepada stake holdersnya yang dalam keseluruhan prosesnya sesuai dengan akad dan prinsipprinsip muamalah dalam Islam. Artinya dalam pemasaran syariah, seluruh 
proses -baik proses penciptaan, proses penawaran, maupun proses perubahan nilai- tidak boleh ada yang bertentangan dengan prinsip-prinsip syariat.

Salah satu hal yang mungkin harus diubah oleh BPRS Irsyadi ialah bagaimana menyikapi atau memosisikan nasabah/konsumen. Konsumen dapat diartikan sebagai siapa saja yang berkepentingan dengan produk layanan yang ditawarkan oleh perusahaan. Konsumen dapat berupa individu (perorangan), pemerintah, maupun swasta. Konsumen atau nasabah merupakan salah satu indikator keberhasilan maju tidaknya suatu perusahaan. Namun seringkali perusahaan mengabaikan konsumen, konsumen hanya dianggap sebagai "sapi perah" dalam menghasilkan keuntungan perusahaan tanpa berupaya untuk memberikan pelayanan prima kepada mereka.

Sementara nasabah dapat didefinisikan sebagai orang atau badan hukum yang mempunyai rekening baik rekening simpanan atau pinjaman pada pihak bank. Sehingga nasabah merupakan orang yang biasa berhubungan dengan atau menjadi pelanggan bank.

Apabila hal ini berlanjut terus-menerus, maka konsumen akan meninggalkan perusahaan karena ketidakpuasan atas pelayanan perusahaan, karena konsumen saat ini sudah "pintar" dan tidak mau dibodohi lagi. Perusahaan harus menempatkan konsumen sebagai raja dalam perusahaan, sehingga setiap elemen perusahaan harus mampu memberikan pelayanan yang terbaik kepada konsumen. Persaingan bisnis saat ini semakin tajam. Setiap perusahaan harus lebih aktif dan lebih agresif dalam merebut posisi pasar dan memenangkan persaingan. Konsep pemasaran perusahaan telah bergeser dari product oriented menjadi customer oriented artinya : tidak hanya memperhatikan mutu/kualitas dari produk tetapi juga memperhatikan kepuasan nasabahnya. Konsep customer oriented dapat diterapkan pada perusahaan yang menghasilkan produk dan mutlak diterapkan pada perusahaan yang bergerak dibidang jasa. Bentuk dari konsep customer oriented ini adalah perusahaan harus lebih memperhatikan nasabahnya dengan cara memberikan pelayanan prima dan selalu menjalin hubungan yang baik sehingga memuaskan keinginan dan kebutuhan nasabah. 
Selama ini paradigma pemasaran yang berkembang adalah perusahaan membuat produk kemudian menawarkannya kepada konsumen agar konsumen bersedia untuk membeli produk tersebut. Konsep ini telah sudah tidak tepat lagi pada era sekarang. Saat ini paradigma yang tengah berkembang adalah dalam melakukan proses pemasaran kepada konsumen, perusahaan harus mampu berpikir seperti konsumen (think like your customer).

Dengan paradigma ini perusahaan berupaya memahami dan berpikir apa yang akan dilakukan, diinginkan oleh konsumen atas keputusan pembeliannya pada suatu produk yang ditawarkan oleh perusahaan. Paradigma merupakan salah strategi efektif dalam memaksimalkan penjualan serta memahami cara dan alasan konsumen dalam membeli produk perusahaan karena produk yang akan diluncurkan oleh perusahaan diharapkan benar-benar yang menjadi kebutuhan dan keinginan dari konsumen.

Dalam dunia bisnis, setiap orang memiliki konsumen -mereka yang membeli, menggunakan, atau mendapatkan manfaat dari apapun yang diproduksi atau dihasilkan oleh perusahaan- dan melayani konsumen merupakan hal paling penting yang harus dilakukan oleh perusahaan termasuk perbankan. Perusahaan harus mampu menjadikan konsumen/nasabah menganggap mereka lebih dari sekedar penjual produk, namun mampu membangun kerjasama yang efektif antara keduanya. Konsumen berharap ada pihak yang datang untuk dapat membantu mereka mengidentifikasi masalahmasalah bisnis yang senantiasa muncul kemudian mampu memberikan solusi untuk mengatasinya dalam rangka mencapai tujuan dan sasaran yang dikehendaki.

Membangun persekutuan antara perusahaan dan konsumen didasarkan pada kerjasama dengan pelanggan untuk mencapai tujuan bersama, yaitu melayani konsumen secara lebih baik. Perusahaan membantu konsumen dengan memberikan produk-produk layanan berkualitas tinggi, lebih cepat dan lebih efektif biaya daripada pesaing mereka. Menjual sesuatu sebenarnya merupakan bagian kecil saja dari kerjasama, kenyataannya jika hanya menjual yang ingin dilakukan oleh perusahaan, konsumen mungkin akan mengetahuinya jauh sebelum perusahaan mendatangi mereka. 
Para konsumen memiliki sensitivitas yang tajam apakah kehadiran perusahaan untuk membantu konsumen atau hanya untuk membantu perusahaan itu sendiri. Tidak ada satu orang konsumen pun yang ingin membeli apa yang dijual oleh perusahaan, namun yang diinginkan oleh konsumen adalah hasil bisnis atau apa yang bisa didapat dengan menggunakan apa yang dijual oleh perusahan. Produk yang dijual oleh perusahaan merupakan sarana untuk mencapai tujuan dan sasaran yang telah ditetapkan oleh konsumen. Misalkan nasabah yang menggunakan layanan prioritas dalam suatu bank, maka yang ingin dicapai oleh nasabah tersebut adalah kemudahan atau kenyamanan pelayanan dalam transaksi yang lebih dari yang didapat oleh nasabah biasa baik pelayanan yang sifatnya lebih cepat atau lebih mudah prosedurnya.

Akan lebih mudah menjual sesuatu kepada seseorang jika aktivitas menjual yang dilakukan perusahaan diposisikan sebagai cara untuk membantu konsumen dalam mencapai atau meraih tujuan dan sasaran yang telah ditetapkan. Perusahaan harus mampu berbicara kepada konsumen mengenai cara-cara baru dalam menjalankan bisnis dan pendekatan-pendekatan baru yang dapat digunakan untuk membuat bisnis lebih menguntungkan dan efisien di masa depan. Dengan layanan prioritas bantuan yang akan diberikan kepada nasabah adalah kemudahan dalam bertransaksi, nasabah prioritas tidak perlu repot antri apabila hendak bertransaksi sebab mempunyai suatu loket tersendiri sehingga mempercepat dan mempermudah proses transaksi. Sebenarnya yang dijual oleh perusahaan bukanlah nilai aktual tetapi nilai yang dirasakan konsumen yang benar-benar penting. Konsumen membeli apa yang mereka butuhkan sehingga mereka dapat memperoleh apa yang mereka inginkan. Mereka tidak menginginkan solusi, yang mereka inginkan adalah hasil (Al Arif, 2010).

Nasabah atau konsumen akan menjadi nasabah yang loyal jika ia merasa puas atas pelayanan yang telah diterima. Salah satu tujuan utama perusahaan khususnya perusahaan jasa -dalam hal ini adalah bank- adalah menciptakan kepuasan pelanggan. Kepuasan pelanggan sebagai hasil penilaian pelanggan terhadap apa yang diharapkannya dengan membeli dan mengkonsumsi suatu produk/jasa. Kemudian harapan tersebut dibandingkan dengan kinerja yang 
diterimanya dengan mengkonsumsi produk/jasa tersebut. Apakah keinginan yang diterimanya lebih besar (minimal sama) daripada harapannya, maka pelanggan puas, sebaliknya kinerja yang diberikan dari pemakaian produk/jasa tersebut lebih kecil daripada apa yang diharapkannya maka pelanggan tidak puas.

Kepuasan konsumen menyatakan bahwa kepuasan dan ketidakpuasan adalah respon konsumen terhadap evaluasi kesesuaian (dis-confirmation) yang dirasakan antara harapan sebelumnya (norma kinerja lainnya) dengan kinerja aktual produk yang dirasakan setelah pemakaiannya. Variabel utama yang menentukan kepuasan konsumen, yaitu expectations (apa yang diharapkan) dan perceived performance (pelayanan yang diterima). Apabila perceived performance melebihi expectations maka pelanggan akan merasa puas, tetapi apabila sebaliknya yaitu perceived performance jauh di bawah expectations maka pelanggan akan merasa tidak puas. Seorang pelanggan yang puas adalah pelanggan yang merasa mendapatkan value (nilai) dari produsen atau penyedia jasa. Nilai ini bisa berasal dari produk, pelayanan, sistem atau sesuatu yang bersifat emosi. Jika pelanggan mengatakan bahwa nilai adalah produk yang berkualitas, maka kepuasan akan terjadi kalau pelanggan mendapatkan produk yang berkualitas (Al Arif, 2010).

Jika nilai bagi pelanggan adalah kenyamanan maka kepuasan akan datang apabila pelayanan yang diperoleh benar-benar dapat membuat konsumen tersebut terasa nyaman. Kalau nilai dari pelanggan adalah harga yang murah maka pelanggan akan puas kepada produsen yang memberikan harga yang paling kompetitif. Jika nilai dalam perbankan bagi pelanggan adalah kemudahan bertransaksi, maka kepuasan pelanggan akan didapat pada bank yang mampu memberikan kemudahan lebih dalam bertransaksi finansial yang dilakukan. Atau jika nilai bagi nasabah adalah tingkat return, maka tingkat return yang tinggilah yang mampu memberikan kepuasan baginya.

Nilai bagi pelanggan ini dapat diciptakan melalui atribut-atribut pemasaran perusahaan yang dapat menjadi unsur-unsur stimuli bagi perusahaan untuk mempengaruhi konsumen dalam pembelian. Jika pembelian yang dilakukan mampu memenuhi kebutuhan dan keinginannya atau mampu 
memberikan kepuasan, maka di masa datang akan terjadi pembelian ulang. Bahkan lebih jauh lagi, konsumen yang puas akan menyampaikan rasa kepuasannya kepada orang lain, baik dalam cerita (word of mouth), atau memberikan rekomendasi.

\section{SIMPULAN}

Berdasarkan hasil analisis, secara parsial layanan jemput bola tidak memiliki pengaruh yang signifikan terhadap DPK dan jumlah nasabah, karena pertama, ruang lingkup BPRS yang belum meluas, karena BPRS Irsyadi belum memiliki cabang ataupun kantor kas, kedua metode promosi yang kurang efektif atau kurangnya sosialisasi pada masyarakat mengenai keuntungan khusus dari layanan jemput bola ini, dan yang ketiga ialah permasalahan-permasalahan teknis pada marketing funding-nya sendiri, seperti kurangnya tenaga marketing funding karena beberapa marketingnya masih merangkap juga sebagai marketing financing. Ketiganya merupakan kemungkinan alasan tidak berpengaruh secara signifikannya layanan jemput bola terhadap DPK dan jumlah nasabah BPRS Irsyadi.

Berdasarkan hasil analisis, secara simultan layanan jemput bola memiliki pengaruh yang signifikan terhadap DPK dan jumlah nasabah. Karena terbantu oleh margin serta KPMM, yang secara parsialnya memiliki pengaruh yang signifikan terhadap DPK dan jumlah nasabah. Sehingga secara keseluruhan ataupun simultan, layanan jemput bola turut serta memiliki pengaruh terhadap DPK dan jumlah nasabah BPRS Irsyadi.

\section{PUSTAKA ACUAN}

Algifari. 1997. Analisis Regresi; Teori, Kasus, dan Solusi. Yogyakarta: BPFE Yogyakarta.

Al Arif, M.N.R. 2010. Dasar-dasar Pemasaran Bank Syariah. Bandung: Alfabeta. Annisa, Safitri Nur. 2013. Persepsi Nasabah Terhadap Sistem Jemput Bola Pada BMT ANDA Salatiga. Salatiga: Stain Salatiga.

Arifin, Z. 2006. Dasar-dasar Manajemen Bank Syariah. Jakarta: Pustaka Alvabet. Buchory, H.A. \& D. Saladin. 2007. Dasar-dasar Pemasaran Bank. Bandung: Linda Karya. 
Budisantoso, T \& S. Triandaru. 2006. Bank dan Lembaga Keuangan Lain. Yogyakarta: Salemba Empat.

Hariyani, T. 2012. Implementasi Manajemen dana Bank Sayriah Dalam Rangka Pencapaian Profit Perusahaan: Studi Pada BPRS Lantabur, Tebuireng, Jombang. Jurnal Fokari, Vol. 1, No. 1, Juli 2012. Hlm. 66-80

Hartanto, J.T. 2010. Analisis Pengaruh Kualitas Pelayanan Jasa Perbankan Terhadap Kepuasan Nasabah: Study Kasus Pada PD. BPR Bank Jogja. (Tesis Tidak Dipublikasikan). Depok: Universitas Gunadarma.

Jundiani. 2009. Pengaturan Hukum Perbankan Syariah di Indonesia. Malang: UIN-Malang Press.

Karim, A.A. 2011. Bank Islam: Analisis Fiqih dan Keuangan. Jakarta: Rajawali Pers.

Kasmir. 2005. Pemasaran Bank. Jakarta: Kencana.

Kuncoro, M. 2009. Metode Riset untuk Bisnis \& Ekonomi: Bagaimana Meneliti \& Menulis Tesis. Jakarta: Erlangga.

Muhammad. 2002. Kebijakan Moneter dan Fiskal dalam Ekonomi Islam. Jakarta: Salemba Empat.

Muljono, T.P. 199. Analisa Laporan Keuangan Untuk Perbankan. Jakarta: Djambatan.

Nachrowi, N.D. \& H. Usman. 2002. Penggunaan Teknik Ekonometrika. Jakarta: PT RajaGrafindo Persada.

Perwataatmadja, K.A. \& H. Tanjung. 2011. Bank Syariah; Teori, Praktik, dan Peranannya. Jakarta: PT Senayan Abadi.

Rofiaty. 2005. Implementasi Strategi Fungsional Bagi Keberhasilan Penerapan Corporate Strategy Pada PT BPR Syariah di Jawa Timur. Tema, Vol. 6, No. 1, Maret 2005. Hlm. 62 - 77

Sulhan. M. \& E. Siswanto. 2008. Manajemen Bank; Konvensional dan Syariah. Malang: UIN-Malang Press.

Ulfa, Lailatul. 2011. Pengaruh Strategi Pemasaran Jemput Bola Terhadap Peningkatan Jumlah Nasabah di UJKS BMT Mitra Umat Pekalongan. (Tesis Tidak Dipublikasikan). Pekalongan: STAIN Pekalongan.

Yuwono, P. 2005. Pengantar Ekonometrika. Yogyakarta: Penerbit Andi. 